\title{
Seminal Fructose Concentration in Different Types of Azoospermia Cases
}

\author{
M. S. Eu Ridi and Lucy Soliman \\ Biochemistry Department \\ A. El Etreby and A. Ibrahim \\ Veneral Disease Department \\ Faculty of Medicine, Cairo University \\ (Z. Naturforschg. 20 b, 773-775 [1965] ; eingegangen am 24. Februar 1965)
}

\begin{abstract}
The results of biochemical and clinical investigations of a number of azoospermia cases are presented. It was found that serious testicular complaint is usually accompanied by a reduction in the volume and a disturbance in the concentration of the constituents of the accessory gland secretion.

Statistical analysis of the fructose concentration indicated that the minimum fructose average was that of the Klinefelter.
\end{abstract}

In 1951, F ARRIS $^{1}$ considered azoospermia cases as the only form of sterility. All other cases were considered either as highly fertile, fertile, sub-fertile according to the magnitude of sperm concentration, motility, and volume but without any reference to the viability of the sperm.

In fact, some azoospermia cases may become fertile on proper surgical intervention namely those who suffer from an organic obstruction. Thus if no, spermatozoa are seen in the semen, biopsy of the testes will show whether the lack is due to blockage in the ductal system, or to an absence of spermatogenesis. Naturally the biopsy will also reveal the state of the semineferous tubules.

Azoospermia due to obstruction is actually the most common cause for the absence of sperm. The other types which are revealed by biopsy are the following:-

1-Azoospermia showing Klinefelter syndrome.

2 - Spermatogenic or maturation arrest.

3 - Azoospermia with disturbed or disorganized spermatogenesis.

4- General aplasia with Sertoli cells only.

1 E. J. FARRIS, Urology 63, 784 [1950].

2 F. X. Gassner and M. L. Hopwood, Proc. Soc. exp. Biol. 81, 37 [1952].

3 S. M. Patridge, Biochem. J. 42, 251 [1948].

4 G. Harris and I. C. MacWilliam, Chem. and Ind. 9, 249 [1954].

\section{Material and Methods}

The present work involves 66 azoospermia subjects in the $19-56$ age group, of which 30 were willing to be investigated by a testicular biopsy. Of these, 9 cases showed normal biopsy, the remaining were divided according to the histological study of the biopsy specimen into the following types:-

a-Kline felt er type (4 cases).

$\mathrm{b}-$ Germinal aplasia or S e r t o li cells only (6 cases).

c- Disturbed or sloughing and disorganized spermatogenesis (5 cases).

d - Spermatogenic arrest (6 cases).

The remaining azoospermia subject (36 cases) who refused biopsy were otherwise tested for volume of semen and further chemically for fructose concentration.

Method for fructose determination

Chromatographic method for separation of fructose from other sugars was used. This consisted of :-

1 - Precipitation of proteins which was performed according to the method of GASNSER and Hopwood ${ }^{2}$.

2 - Solvent used for the separation of sugars is butanol-acetic - water $(4: 1: 5),\left(\mathrm{P}_{\text {ATRIDGE }}{ }^{3}\right)$.

3 - The method for detecting the separated spots is the dipping technique of $\mathrm{H}_{\text {ARRIS }}{ }^{4}$ using the aniline phthalate solution as indicated by PATRIDGE ${ }^{5}$.

4 - Extraction of the unstained spot by modified Blass ${ }^{6}$ method (1950).

5 - Roe Selivanoff ${ }^{7}$ reaction test was applied for the colour reaction.

5 S. M. Patridge, Nature [London] 166, 443 [1949].

6 J. Blass, M. Macheboeuf, and G. Nunes, Bull. Soc. Chim. biol. 32, 130 [1950].

7 J. H. Roe, J. biol. Chemistry 183, 739 [1934]. 


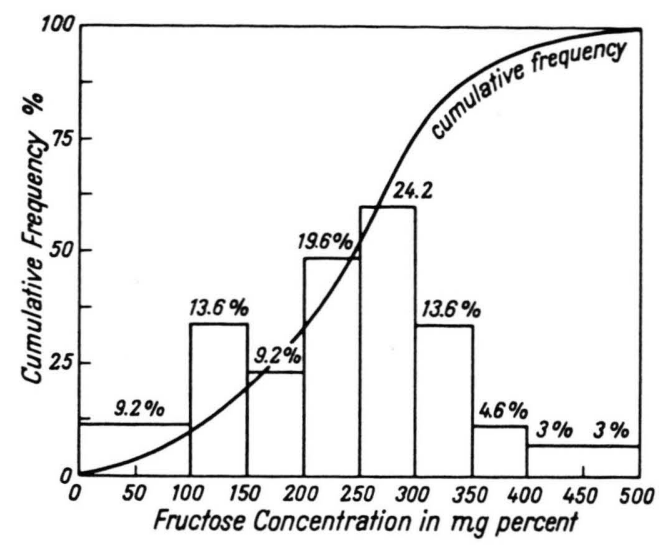

Fig. 1. Histogram for Fructose Concentration - Azospermia Group.

\section{Results}

The investigation gave an overall average for volume $2.73 \mathrm{ml}$, range $(0.5-8 \mathrm{ml})$ and $233 \mathrm{mg}$ fructose, range $(0-446) \mathrm{ml}$.

\begin{tabular}{|c|c|c|c|}
\hline Types of Biopsy & $\begin{array}{l}\text { No. of } \\
\text { individ. }\end{array}$ & $\begin{array}{l}\text { Aver. Vol. } \\
{[\mathrm{ml} .]}\end{array}$ & $\begin{array}{l}\text { Average } \\
\text { fructose } \\
{[\mathrm{mg} . \mathrm{-} \%]}\end{array}$ \\
\hline $\begin{array}{l}\text { 1. KLINEFELTER } \\
\text { syndrome }\end{array}$ & 4 & 1.63 & 163 \\
\hline $\begin{array}{l}\text { 2. Germinal aplasia or } \\
\text { SERTOLI cells only. }\end{array}$ & 6 & 2.17 & 330 \\
\hline $\begin{array}{l}\text { 3. Disturbed or } \\
\text { disorganized } \\
\text { spermatogenesis. }\end{array}$ & 5 & 2.83 & 231 \\
\hline $\begin{array}{l}\text { 4. Non biopsy } \\
\text { 5. Spermatogenic }\end{array}$ & 36 & 2.92 & 228 \\
\hline Arrest & 6 & 3.13 & 250 \\
\hline $\begin{array}{l}\text { biopsy } \\
\text { (obstructive). }\end{array}$ & 9 & 3.25 & 264 \\
\hline
\end{tabular}

Table 1. Averages of volume and fructose concentration in the different azoospermia types.

\begin{tabular}{|c|c|c|c|}
\hline $\begin{array}{c}\text { Fructose } \\
\text { class } \\
\text { [mg. \%] }\end{array}$ & $\begin{array}{c}\text { No. of } \\
\text { individ. }\end{array}$ & $\begin{array}{c}\text { \% of } \\
\text { Total }\end{array}$ & $\begin{array}{c}\text { Cumulative } \\
\text { frequency } \\
{[\%]}\end{array}$ \\
\hline $450-500$ & 2 & 3 & 100.0 \\
$400-350$ & 2 & 3 & 97.0 \\
$350-399$ & 3 & 4.6 & 94.0 \\
$300-349$ & 9 & 13.6 & 89.4 \\
$250-299$ & 16 & 24.2 & 75.8 \\
$200-249$ & 13 & 19.6 & 51.6 \\
$150-199$ & 6 & 9.2 & 32.0 \\
$100-149$ & 9 & 13.6 & 22.8 \\
$50-99$ & 3 & 4.6 & 9.2 \\
$0-49$ & 3 & 4.6 & 4.6 \\
\hline
\end{tabular}

Table 2. Frequency distribution of fructose in Azoospermia.
Detailed results are summarized in Tables 1 and 2.

The corresponding histogram is given below, which shows a clear mode in the interval $250-299$.

\section{Discussion}

It may be noted that, the $2.73 \mathrm{ml}$ overall average for volume was found significantly lower than normal $^{8}$, namely 3.35 and is almost the same as that of McLeod ${ }^{9} 2.72$, obtained from a sample of 300 . Further it was found that the highest average volume is that for the normal testicular biopsy people namely $3.25 \mathrm{ml}$ which is only slightly lower than that for the normally fertile. Next in order of magnitude comes the average for the cases of spermatogenic arrest and non biopsy followed by the rest of the cases.

The minimum average was $1.63 \mathrm{ml}$ for the small sample of 4 cases of $\mathrm{K} \mathrm{lin}$ e f e l t e r syndrome. The average value for those who refused biopsy is 2.92 $\mathrm{ml}$ which, if taken at its face value, would indicate that in this group the frequency of the normal biopsy and spermatogenic arrest is more than the three other more serious complaints. This agrees with the conclusion of VaIshwahnar ${ }^{10}$ (1958) and would mean that serious testicular complaint is normally accompanied by a reduction in the volume and a disturbance in the concentration of the secretion of the accessory glands. The dependence therefore is not only on the Ley dig cells but also on the general condition of the testes.

The fructose figure lends another proof of this conclusion. Its results may be arranged as follows: Germinal aplasia or azoospermia with Sertoli cells only $330 \mathrm{mg}-\%$, normal testicular biopsy 264 , spermatogenic arrest 250 , non biopsy 228 , disturbed or disorganized spermatogenesis $187, \mathrm{Kl}$ in e f e l t e r $163 \mathrm{mg}$ while the normally fertile ${ }^{8} 260 \mathrm{mg}$ per cent.

Therefore, those who came nearest to the normal figure are the obstructive cases and spermatogenic arrest. The farthest figure are those with Sertoli cells only (difference $=+70 / 260$ ) and the K lin e f el t e r cases (difference $=-97 / 260$ ).

The high average fructose concentration of the azoospermia with Sertoli cells only may be due

8 M. S. El Ridi, L. Soliman, A. El Etrebi, and A. Ibrahim, Egypt, Pharmacie, Bull. 44, No. 4, April [1962].

9 J. McLeod, Fertility, Sterility 7, 368 [1956].

10 P. S. Vaishwahnar, Amer. J. Obstetr. Gynecol. 75, 139 [1958]. 
to the increased secretion of testosterone by the abnormally large number of Ley dig cells; while in the $\mathrm{Kl}$ in ef el te r type a very low fructose average indicates that the Leydig cells are not normal. This latter agrees well with the findings of HeLLen and Nelson ${ }^{11}$ 1948, that some of the K lin ef el te $\mathrm{r}$ syndrome are accompanied by hypoleydigism.

\section{Summary and Conclusion}

1 - 66 azoospermia subjects were investigated both biochemically and clinically.

2 - Some of them biopsied and histological examination of the biopsy studied.

11 C. G. Heller and W. O. Nelson, J. Clin. Endocrinol. 8, 345 [1948].
3 - Fructose concentration was determined and compared with the fructose concentration of normal fertile subjects.

4 - Statistical analysis of the fructose concentration was performed resulting in that, the minimum fructose average was that of the Kline felter azoospermia, while those who have normal testicular biopsy and suffer from anorganic obstruction showed a fructose average which is remarkably near that of the fertile. This result is naturally expected for it indicates that the hormonal link between the primary and accessory sexual glands is unaffected by any organic obstruction. In other words the result lends a further proof that the balance between both sets of glands is purely hormonal.

\title{
Bemerkungen zuVeränderungen bei elektronenmikroskopischen Schnitten durch den abbildenden Elektronenstrahl und zur Struktur der eingebetteten Gewebe
}

\author{
W. LIPPERT \\ Max-Planck-Institut für Biophysik, Frankfurt a. M. (Direktor: Prof. Dr. Dr. Dr. Dr. Dr. B. RAJEwsky) \\ (Z. Naturforschg. 20 b, 775-778 [1965]; eingegangen am 3. Februar 1965) \\ Es wird auf die Mannigfaltigkeit der Kontraste hingewiesen, die sich bei mit Aldehyden fixier- \\ tem, in Vestopal W oder Durcupan ACM eingebettetem Gewebe durch gesteuerte Elektronen- \\ bestrahlung erreichen läßt. Voraussetzung für einen einwandfreien Vergleich von Kontrasten bei \\ z. B. verschieden gefärbten Schnitten ist daher eine Bestrahlung, die zu ausreichend definierten \\ Objektveränderungen führt. Brauchbar in diesem Sinne ist eine Bestrahlung, die zum maximalen \\ „reinen Strahlenverlust“ führt, bei der aber thermische Substanzverluste vermieden werden. Der \\ Negativkontrast von Chromatin und Nucleolen und die offenbar physikalisch bedingte Färbbarkeit \\ der nucleinsäurehaltigen Zellbestandteile mittels der „negative-staining“-Methode werden diskutiert.
}

Bei elektronenmikroskopischen Schnitten lassen sich genauere Aussagen gewinnen, wenn der Kontrast der Zellbestandteile zur Auswertung mit herangezogen werden kann. Die Kontrastverhältnisse sind aber auch von der Art der Elektronenbestrahlung des Objekts abhängig, und es ist daher in solchen Fällen erforderlich, die durch die Bestrahlung eintretenden Objektveränderungen zu kennen und entsprechend zu berücksichtigen. Die bisher bei eingebettetem Gewebe gewonnenen Erkenntnisse ${ }^{1}$ beziehen sich im wesentlichen auf OsmiumtetroxydFixierung und Methacrylat-Einbettung. Sie lassen sich aus leicht ersichtlichen Gründen wenigstens

1 Zum Beispiel C. Morgan, D. H. Moore u. H. M. Rose, J. biophys. biochem. Cytol. Suppl. 2, 21 [1956]. quantitativ nicht ohne weiteres auf die heute übliche Aldehyd-Fixierung und die Einbettung in Vestopal W oder Araldit (Durcupan ACM) übertragen.

Bei Kontraständerungen an Schnitten ist zu unterscheiden zwischen den Veränderungen an den Einbettungsmitteln und den am eigentlichen biologischen Material. Etwas verallgemeinernd läßt sich sagen, daß diese Veränderungen sich in zwei verschiedenen Bereichen der Objektladungsdichte vollziehen und daher einigermaßen gut trennbar sind. Die neueren Einbettungsmittel zeigen Kontraständerungen im Objektladungsdichte-Bereich zwischen ungefähr $10^{-3}$ und $10^{-1} \mathrm{C} / \mathrm{cm}^{2}$. Der entsprechende Bereich für biologische Strukturen liegt, soweit bis jetzt bekannt, um ungefähr drei Zehnerpotenzen höher. 